\title{
MENINGKATKAN KEMAMPUAN MEMBACA PEMAHAMAN MELALUI STRATEGI PEMBELAJARAN KNOW WANT-LEARNED (KWL) SISWA KELAS IV-B SD NEGERI 24 KENDARI
}

\author{
Rehzky Qur'ana ${ }^{1)}$, Mansyur $\mathrm{M}^{1)}$, La Rabani ${ }^{1)}$ \\ 1) Jurusan Pendidikan Guru Sekolah Dasar \\ FKIP Universitas Halu Oleo \\ Email: rehzkyqurana092@gmail.com, mansyurm919@gmail.com, larabani59@gmail.com
}

\begin{abstract}
Abstrak: Penelitian ini dilatarbelakangi dengan rendahnya kemampuan siswa dalam memahami isi bacaan khususnya dalam pembelajaran Bahasa Indonesia. Salah satu sebab rendahnya kemampuan siswa dalam memahami isi bacaan yaitu karena kegiatan pembelajaran yang dilakukan oleh guru masih bersifat kovensional. Adapun rumusan masalah dalam penelitian ini adalah "apakah melalui strategi pembelajaran Know-Want-Learned (KWL) pada tema 7 indahnya keragaman di negeriku dapat meningkatkan kemampuan membaca pemahaman siswa kelas IV-B SD Negeri 24 Kendari?." Tujuan dalam penelitian ini adalah untuk meningkatkan kemampuan membaca pemahaman siswa pada tema 7 indahnya keragaman di negeriku melalui penerapan strategi pembelajaran KWL (Know-Want-Learned). Penelitian ini merupakan penelitian tindakan kelas yang dilakukan dalam dua siklus. Tiap siklus terdiri dari empat tahap yaitu perencanaan, pelaksanaan, observasi dan refleksi. Penelitian ini dilaksanakan pada semester genap tahun ajaran 2019/2020 bertempat di Kelas IV-B SDN 24 Kendari. Subjek dalam penelitian ini adalah guru dan siswa kelas IV-B SDN 24 Kendari, dengan jumlah siswa 20 orang yang terdiri dari 6 orang siswa perempuan dan 14 orang siswa laki-laki. Teknik pengumpulan data dilakukan melalui observasi dan tes. Teknik analisis data menggunakan deskriptif kualitatif dan deskriptif kunatitatif. Hasil penelitian menunjukkan bahwa persentase ketuntasan klasikal kemampuan membaca pemahaman siswa pada siklus I sebesar 55\% dengan rata-rata nilai 77,25 dan pada siklus II meningkat menjadi $85 \%$ dengan rata-rata nilai 84,8 . Berdasarakan hasil penelitian tersebut dapat disimpulkan bahwa penerapan strategi pembelajaran Know-Want-Learned (KWL) dapat meningkatkan kemampuan membaca pemahaman siswa kelas IV-B SDN 24 Kendari.
\end{abstract}

Kata Kunci: Strategi pembelajaran KWL; kemampuan membaca pemahaman

\section{IMPROVING UNDERSTANDING READING ABILITY THROUGH THE KNOW WANT-LEARNED (KWL) STRATEGY LEARNING CLASS IV-B STUDENTS OF SD NEGERI 24 KENDARI}

\begin{abstract}
This research was motivated by the low ability of students to understand the contents of reading, especially in learning Indonesian. One reason for the lack of ability of students to understand the contents of reading is because learning activities carried out by teachers are still conventional. The research problem was "can the Know-Want-Learned (KWL) learning strategy on the theme of 7 the beauty of diversity in my country improve the reading comprehension ability of students in class IV-B at SD Negeri 24 Kendari?". The purpose of this research was to improve students' reading comprehension on the theme of 7 of the beauty of diversity in my country through the application of the KWL (Know-Want-Learned) learning strategy. This research was a Classroom Action Research (CAR) conducted in two cycles. Each cycle consisted of four stages: planning, implementing, observing and reflecting. This research was conducted in the even semester of the 2019/2020 school year at the Class IV-B of SDN 24 Kendari. The subjects in this study were teachers and students enrolled in Class IV-B at SDN 24 Kendari, with a total of 20 students consisting of 6 female students and 14 male students. Data collection techniques were done through observation and tests. Data analysis techniques used in this research were descriptive qualitative and descriptive quantitative. The results showed that the percentage of classical completeness of reading comprehension of students in the first cycle was 55\% with an average value of 77.25 and in the second cycle increased to $85 \%$ with an average value of 84.8. Based on these results, it can be concluded that the application of the Know-Want-Learned $(K W L)$ learning strategy can improve the reading comprehension skills of students in class IV-B at SDN 24 Kendari.
\end{abstract}

Keyword: KWL learning strategy; reading comprehension ability 


\section{Pendahuluan}

Salah satu keterampilan berbahasa yang harus dikuasai siswa adalah keterampilan membaca. Keterampilan membaca sangat penting dimiliki untuk memperoleh ilmu pengetahuan, karena pengetahuan dapat diperoleh melalui kegiatan membaca. Dengan membaca, seseorang dapat memperoleh informasi yang diperlukan bahkan memperoleh pengetahuan baru yang belum diketahui sebelumnya. Memiliki kemampuan atau keterampilan membaca itu sangat penting dalam kehidupan manusia. Salah satu jenis keterampilan membaca yaitu membaca pemahaman. Kemampuan memahami isi bacaan tidak hanya dibutuhkan oleh masyarakat akademis, tetapi juga diperlukan oleh berbagai kalangan masyarakat yang ingin memperoleh informasi melalui media tulis. Sebagai kegiatan yang bertujuan untuk memperoleh informasi, kemampuan pemahaman isi bacaan merupakan hal yang cukup penting, sebagaimana Bormuth dalam Herlinyanto $(2015$, p. 1) menyatakan bahwa "kemampuan pemahaman dipandang sebagai keterampilan untuk memperoleh pengetahuan dan memperluas informasi sebagai hasil dari kegiatan membaca bahasa tulis."

Dalam pelajaran Bahasa Indonesia di SD membaca diajarkan dengan menggunakan berbagai jenis keterampilan membaca untuk memahami wacana berupa petunjuk, teks panjang dan berbagai karya sastra untuk anak berbentuk puisi, dongeng, pantun, percakapan, cerita dan drama. Kegiatan pembelajaran pada mata pelajaran lain pun tidak dapat lepas dari kegiatan membaca. Semakin berkualitas keterampilan membaca siswa maka akan semakin mudah dalam mempelajari bidang studi yang lainnya. Walau demikian, masih banyak siswa yang belum menyadari pentingnya membaca untuk mendukung prestasi belajar mereka. Fenomena saat ini, di Indonesia ditemukan bahwa minat membaca siswa masih rendah, sebagaimana yang dituturkan Umam dalam Maulana (2018, p. 49-50) bahwa data Progress in International Reading Literacy Study (PIRLS) yang meneliti siswa kelas IV SD menunjukkan bahwa prestasi membaca siswa Indonesia sangat rendah. Kemampuan membaca siswa Indonesia berada pada urutan ke-45 dari 49 negara yang diteliti. Skor Indonesia adalah (405) berada di atas Qatar (353), Maroko (323), dan Afrika Selatan (302).

Permasalahan yang terjadi dalam pembelajaran Bahasa Indonesia khususnya pada aspek membaca penting untuk guru perhatikan di kelas. Karena, ketika seseorang mengalami permasalahan dalam keterampilan membacanya maka hampir dapat dipastikan seseorang tersebut tidak akan mampu memahami bacaan ataupun teks yang telah dibaca. Selain itu, kegagalan dalam pembelajaran membaca pada mata pelajaran Bahasa Indonesia secara langsung maupun tidak langsung akan mempengaruhi ketidakberhasilan dalam mata pelajaran lain. Karena sejatinya kegiatan membaca tidak hanya digunakan dalam mata pelajaran Bahasa Indonesia, namun juga digunakan dalam mata pelajaran lain sebagai sarana memahami materi maupun memahami soal.

Permasalahan dalam pembelajaran membaca pemahaman juga terjadi di kelas IV-B SD Negeri 24 Kendari. Berdasarkan hasil wawancara dengan guru kelas IV-B SD Negeri 24 Kendari yang bernama Ibu Mahri pada tanggal 25 Oktober 2019, diketahui bahwa nilai KKM yang harus dicapai siswa adalah 75. Informasi yang peneliti peroleh bahwa data hasil belajar siswa pada tema 7 yang terdiri dari 26 siswa hanya 10 orang siswa $(38,46 \%)$ yang mencapai nilai KKM dengan nilai rata-rata 71,54. Ini menunjukkan bahwa lebih dari setengahnya atau 16 siswa tidak mencapai nilai KKM, salah satu faktor penyebab dari rendahnya hasil belajar siswa adalah kemampuan siswa di dalam memahami isi bacaan masih sangat rendah atau sangat kurang. Ketidakmampuan siswa dalam memahami isi bacaan tentu mempengaruhi hasil belajar siswa, seperti yang diungkapkan oleh Nurgiyantoro dalam Nurcahyanti (2018, p. 195) bahwa kemampuan membaca pemahaman merupakan kunci keberhasilan siswa dalam menjalani proses pendidikan, sebagian besar pemerolehan ilmu dilakukan siswa melalui aktivitas membaca, dalam hal ini membaca pemahaman. Terlebih diketahui bahwa salah satu kompetensi dasar membaca kelas IV pada kurikulum 2013 yaitu menggali pengetahuan baru yang terdapat pada teks nonfiksi (Silabus Tematik Terpadu SD/MI Kelas IV Semeseter 2 Tema 7). Selain itu, diketahui pula bahwa pada kurikulum 2013 mengintegrasikan beberapa mata pelajaran dalam satu pembelajaran dalam bentuk tematik, sehingga ketika siswa tidak mampu memahami isi bacaan tentu akan berdampak pada hasil belajarnya. 
Berdasarkan pada permasalahan tersebut, banyak faktor yang dapat menyebabkan siswa sulit dalam memahami isi bacaan, salah satu diantaranya yaitu model atau strategi pembelajaran yang digunakan oleh guru. Observasi awal yang dilakukan peneliti pada tanggal 25 Oktober 2019, peneliti menemukan kegiatan pembelajaran yang dilakukan guru masih bersifat konvensional, guru memberikan tugas pada siswa untuk menulis dan menjawab soal-soal sesuai dengan teks bacaan yang ada pada halaman yang ditunjukan secara berurutan, tanpa memotivasi siswa untuk dapat memahami isi bacaan. Tentu hal tersebut membuat siswa menjadi kurang bersemangat dalam pembelajaran, sehingga berdampak pada hasil belajar yang dicapai menjadi tidak maksimal, untuk itu guru perlu mencari model atau strategi pembelajaran yang memungkinkan dapat meningkatkan kemampuan membaca pemahaman siswa. Salah satu strategi yang dapat diterapkan adalah strategi pembelajaran KWL (Know-Want-Learned). Strategi KWL dapat membantu siswa memahami informasi baru yang diterimanya. Strategi ini dipilih karena langkah-langkah strategi pembelajaran KWL cukup sederhana dan jelas serta memiliki dampak signifikan apabila diterapkan untuk kegiatan membaca pemahaman. Melalui strategi KWL, siswa dapat mengingat bacaan lebih lama, karena strategi ini menekankan siswa untuk memahami apa yang telah dibacanya dan terarah pada pokok dalam suatu bacaan sehingga siswa juga dapat memperoleh informasi baru melalui bacaan yang dibacanya.

Berdasarkan permasalahan yang telah diidentifikasi, maka peneliti menindaklanjuti dengan mengadakan Penelitian Tindakan Kelas dengan mengambil judul "Meningkatkan Kemampuan Membaca Pemahaman Melalui Strategi Pembelajaran Know-Want-Learned (KWL) Siswa Kelas IV-B SD Negeri 24 Kendari.”

\section{Metode Penelitian}

Penelitian ini termasuk dalam jenis penelitian Classroom Action Research (CAR) atau biasa disebut Penelitian Tindakan Kelas (PTK). Penelitian ini dilaksanakan di SDN 24 Kendari yang berlokasi di Jl. Damai No. 1, Kel. Gunung Jati, Kec. Kendari, Kota Kendari, Provinsi Sulawesi Tenggara. Subjek dalam penelitian ini adalah Guru Kelas IV-B dan siswa kelas IV-B SD Negeri 24 Kendari yang terdaftar dan aktif pada semester genap tahun ajaran 2019/2020, dengan jumlah siswa 20 orang yang terdiri dari 6 orang siswa perempuan dan 14 orang siswa laki-laki. Faktor yang diteliti dalam penelitian ini adalah 1) faktor siswa, yaitu aktivitas belajar siswa dan hasil belajar siswa berupa kemampuan memahami isi bacaan, dan 2) Faktor guru. Penelitian Tindakan Kelas ini dilaksanakan dalam 2 (dua) siklus. Adapun prosedur penelitian tindakan ini meliputi: (1) Perencanaan, (2) Pelaksanaan Tindakan, (3) Observasi dan Evaluasi, dan (4) Refleksi dalam setiap siklus. Jenis data yaitu data kualitatif dan data kuantitatif. Data kualitatif diperoleh melalui observasi, menggunakan lembar observasi sedangkan data kuantitatif diperoleh melalui tes setiap akhis siklus tindakan. Data kualitatif akan dianalisis menggunakan deskriptif kualitatif. Sedangkan data kuantitatif akan dianalisis menggunakan deskripstif kuantitatif. Pengolaan data dilakukan setelah semua data terkumpul, selanjutnya akan dianalisis secara kuantitatif yaitu dengan mencari skor nilai rata-rata dan presentase siswa, dan secara kuanlitatif dilakukan terhadap data yang diperoleh melalui observasi aktivitas belajar siswa dan guru dalam penerapan strategi KWL untuk meningkatkan keterampilan membaca. Untuk mengetahui pencapaian kriteria nilai rata-rata siswa yaitu dengan menganalisis semua nilai yang diperoleh siswa kemudian dibagi dengan semua jumlah siswa yang mengikuti tes penelitian tersebut.

\section{Hasil Penelitian}

\section{Deskripsi Hasil Observasi Penelitian (Aktivitas Pelaksanaan Pembelajaran)}

Berikut peneliti sajikan hasil rekapitulasi aktivitas pelaksanaan pembelajaran yang telah dilakukan baik oleh guru maupun siswa sesusai dengan langkah-langkah stretegi pembelajaran KWL, untuk meli hat seberapa besar persentase keterlaksanaan menggunakan strategi tersebut. 


\section{a. Aktivitas Mengajar Guru}

Berikut adalah hasil rekapitulasi observasi aktivitas mengajar guru menggunakan strategi pembelajaran KWL yang dilakukan selama dua siklus yang disajikan dalam bentuk tabel. Tabel 1. Perbandingan Hasil Observasi Aktivitas Mengajar Guru Siklus I dan Siklus II

\begin{tabular}{clcccc}
\hline \multirow{2}{*}{ No } & \multirow{2}{*}{ Uraian } & \multicolumn{4}{c}{ Hasil Pengamatan } \\
\cline { 3 - 6 } & & \multicolumn{3}{c}{ Siklus I } & \multicolumn{2}{c}{ Siklus II } \\
\cline { 3 - 6 } & & Pert. 1 & Pert. 2 & Pert. 1 & Pert. 2 \\
\hline 1. & Skor Perolehan & 10 & 16 & 15 & 17 \\
\hline 2. & Skor Maksimal & 17 & 17 & 17 & 17 \\
\hline 3. & Persentase & $59 \%$ & $94 \%$ & $88 \%$ & $100 \%$ \\
\hline 4. & Rata-rata & \multicolumn{3}{c}{76,5} & \multicolumn{3}{c}{94} \\
\hline
\end{tabular}

Berdasarkan tabel 1 di atas, menunjukkan bahwa pada siklus I pertemuan 1 skor yang diperoleh sebanyak 11 dan pada pertemuan 2 sebanyak 16 dari jumlah skor yang ditetapkan yakni 17 dengan persentase keterlaksanaan 59\% pada pertemuan 1 dan $94 \%$ pada pertemuan 2 . Sementara pada siklus II pertemuan 1 skor yang diperoleh sebanyak 15 dan pada pertemuan 2 sebanyak 17 dengan persentase keterlaksanaan $88 \%$ pada pertemuan 1 dan $100 \%$ pada pertemuan 2. Jika persentase keterlaksanaan pada setiap pertemuan untuk kedua siklus dirata-ratakan maka diperoleh rata-rata keterlaksanaan pada siklus I sebesar 76,5 dan pada siklus II sebesar 94.

b. Aktivitas Belajar Siswa

Berikut adalah hasil rekapitulasi observasi aktivitas belajar siswa selama diterapkannya strategi pembelajaran KWL yang dilakukan selama dua siklus yang disajikan dalam bentuk tabel. Tabel 2. Perbandingan Hasil Observasi Aktivitas Belajar Siswa Siklus I dan Siklus II

\begin{tabular}{|c|c|c|c|c|c|}
\hline \multirow{3}{*}{ No } & \multirow{3}{*}{ Uraian } & \multicolumn{4}{|c|}{ Hasil Pengamatan } \\
\hline & & \multicolumn{2}{|c|}{ Siklus I } & \multicolumn{2}{|c|}{ Siklus II } \\
\hline & & Pert. 1 & Pert. 2 & Pert. 1 & Pert. 2 \\
\hline 1. & Skor Perolehan & 7 & 10 & 15 & 16 \\
\hline 2. & Skor Maksimal & 16 & 16 & 16 & 16 \\
\hline 3. & Persentase & $44 \%$ & $63 \%$ & $94 \%$ & $100 \%$ \\
\hline 4. & Rata-rata & \multicolumn{2}{|c|}{53,5} & \multicolumn{2}{|c|}{97} \\
\hline
\end{tabular}

Berdasarkan tabel 2 di atas, menunjukkan bahwa pada siklus I pertemuan 1 skor yang diperoleh sebanyak 7 dan pada pertemuan 2 sebanyak 10 dari jumlah skor yang ditetapkan yakni 16 dengan persentase keterlaksanaan $44 \%$ pada pertemuan 1 dan $63 \%$ pada pertemuan 2 . Sementara pada siklus II pertemuan 1 skor yang diperoleh sebanyak 15 dan pada pertemuan 2 sebanyak 16 dengan persentase keterlaksanaan $94 \%$ pada pertemuan 1 dan $100 \%$ pada pertemuan 2 . Jika persentase keterlaksanaan pada setiap pertemuan untuk kedua siklus dirata-ratakan maka diperoleh rata-rata keterlaksanaan pada siklus I sebesar 53,5 dan pada siklus II sebesar 97.

Dari hasil observasi yang telah dilakukan pada saat pelaksanaan tindakan siklus I menurut pengamatan observer, aktivitas pelaksanaan pembelajaran masih perlu ditingkatkan karena masih terdapat beberapa kekurangan yang dilakukan dan hal itu mempengaruhi jalannya proses pelaksanaan kegiatan pembelajaran menggunakan strategi pembelajaran KWL, yakni guru pada saat memulai pembelajaran tidak menjelaskan tujuan pembelajaran dan kurang memotivasi siswa sehingga siswa belajar kurang terarah dan kurang bersemangat. Guru juga tidak menyampaikan tahapan kegiatan secara rinci sehingga siswa belum sepenuhnya paham dengan strategi KWL. Demikian pula perhatian siswa, tidak semua siswa fokus dalam memperhatikan penjelasan dari guru dan juga ketika membaca dikarenakan suasana pembelajaran yang kurang kondusif. Selain itu komunikasi antara siswa dan guru yang kurang baik, disertai rasa malu-malu bertanya dari siswa untuk mengemukakan pendapatnya dan juga saat diskusi kelompok hanya beberapa siswa yang mendominasi sehingga membuat pembelajaran membaca pemahaman dengan penerapan strategi 
KWL kurang berhasil. Karena pelaksanaan tindakan siklus I belum mencapai target indikator keberhasilan penelitian yang ditentukan, sehingga peneliti bersama guru berkolaborasi merencanakan tindakan pada siklus II. Kelemahan dan kekurangan yang ada pada siklus I akan diperbaiki pada siklus II, begitupun keberhasilan-keberhasilan pada siklus I akan dipertahankan dan ditingkatkan di siklus II.

Hasil observasi pada saat pelaksanaan tindakan siklus II ini menunjukkan adanya peningkatan dikarenakan proses pembelajaran telah berjalan dengan baik sesuai dengan yang direncanakan. Menurut pengamatan observer, guru pada saat memulai pelajaran telah menjelaskan tujuan pembelajaran sehingga kegiatan belajar siswa menjadi terarah. Guru juga telah memotivasi siswa dan memberikan apersepsi yang berkaitan dengan kehidupan sehari-hari siswa sehingga membuat siswa bersemangat dan antusias untuk belajar. Guru juga telah menyampaikan tahapan kegiatan pembelajaran dengan menggunakan strategi KWL sehingga siswa menjadi paham dengan apa yang akan dilakukan selama kegiatan pembelajaran berlangsung. Selain itu guru juga telah menciptakan suasana pembelajaran yang menyenangkan, bebas dari gangguan baik dari luar maupun dari dalam kelas serta telah berusaha melakukan penataan kelas dengan baik sehingga membuat siswa menjadi lebih fokus saat membaca maupun ketika memperhatikan penjelasan dari guru. Guru juga mulai memberikan perhatian, bimbingan dan komunikasi yang baik dengan siswa sehingga membuat siswa ketika berdiskusi menjadi lebih berperan aktif dibanding siklus sebelumnya dan tidak lagi malu-malu atau takut untuk menyampaikan pendapatnya.

\section{Deskripsi Hasil Evaluasi Penelitian (Kemampuan Membaca Pemahaman Siswa)}

Berdasarkan hasil tes siklus I, dari 20 orang siswa yang mengikuti tes terdapat 11 orang siswa yang memiliki nilai dengan kategori tuntas (memperoleh nilai $\geq 75$ ) dengan presentase $55 \%$ sedangkan 9 orang lainnya belum tuntas (memperoleh nilai $\leq 75$ ) dengan presentase $45 \%$ dengan rata-rata nilai sebesar 77,25. Sedangkan, pada siklus II terdapat 17 orang siswa yang telah memenuhi kriteria ketuntasan belajar dengan persentase ketuntasan sebesar $85 \%$ dengan rata-rata nilai sebesar 84,8 . Sehingga, dapat dikatakan bahwa pada siklus II sebagian besar siswa sudah dapat memahami isi bacaan dengan baik terutama dalam menjawab pertanyaan berdasarkan teks, menemukan informasi baru atau penting dari teks, menentukan ide pokok dan menyimpulkan isi teks bacaan dalam satu kalimat. Untuk lebih jelasnya dapat dilihat pada Tabel 3 di bawah ini.

Tabel 3. Hasil Tes Kemampuan Membaca Pemahaman Siswa Siklus I dan Siklus II

\begin{tabular}{|c|c|c|c|}
\hline \multirow{2}{*}{ Hasil Belajar } & \multicolumn{2}{|c|}{ Ketuntasan Hasil Belajar Siswa } & \multirow{2}{*}{ Rata-Rata Nilai } \\
\hline & Tuntas (\%) & Tidak Tuntas (\%) & \\
\hline Siklus I & 45 & 55 & 77,25 \\
\hline Siklus II & 85 & 15 & 84,8 \\
\hline
\end{tabular}

\section{Pembahasan}

\section{Aktivitas Pelaksanaan Pembelajaran}

Berdasarkan hasil penelitian yang telah dipaparkan dapat dikatakan bahwa aktivitas pelaksanaan pembelajaran menggunakan strategi pembelajaran KWL pada siklus II telah berhasil diterapkan. Keberhasilan pelaksanaan pembelajaran tersebut tidak lepas dari peran guru sebagai pengelola pembelajaran yang menjadi komponen utama untuk keberhasilan proses pembelajaran, hal ini sebagaimana pendapat Sanjaya (2011, p. 3) yang mengatakan bahwa proses pembelajaran dapat dianggap sebagai suatu sistem. Dengan demikian keberhasilannya dapat ditentukan oleh berbagai komponen yang membentuk sistem itu sendiri, salah satunya yaitu guru. Sebab guru merupakan ujung tombak yang secara langsung berhubungan dengan siswa sebagai objek dan subjek belajar. Oleh karena itu, berkualitas dan tidaknya proses pembelajaran sangat tergantung pada kemampuan dan perilaku guru dalam pengelolaan pembelajaran. Dengan kata lain merupakan faktor penting yang dapat menentukan kualitas pembelajaran. Guru juga telah mampu menciptakan kondisi kelas yang lebih kondusif sehingga pembelajaran menjadi lebih efektif dan menyenangkan. Selain karena perannya sebagai pengelola pembelajaran, kemampuan guru juga dalam memberikan motivasi dan penguatan terhadap respon siswa membuat siswa menjadi lebih bersemangat dan 
antusias dalam belajar serta berani untuk menyampaikan pendapatnya, hal ini sejalan dengan pendapat Melinda \& Susanto (2018, p. 82) bahwa motivasi adalah suatu proses untuk menggiatkan motif menjadi perbuatan atau tingkah laku untuk memenuhi kebutuhan dan mencapai tujuan tertentu. Dalam hal belajar diartikan sebagai keseluruhan daya penggerak dalam diri siswa untuk melakukan serangkaian kegiatan belajar guna mencapai tujuan yang telah ditetapkan. Pemberian motivasi dapat dilakukan oleh guru dengan memberikan sugesti-sugesti positif ketika siswa merasa tertekan atau stres. Hal ini disebabkan ketika sedang stres, hormon norefinephrin akan terangsang sehingga menstimulasi pengambilan keputusan dan memotivasi siswa dalam belajar (Johnson dalam Rustan, 2017, p. 17).

Aktivitas belajar siswa dipengaruhi oleh aktivitas mengajar guru, jika aktivitas mengajar guru terlaksana dengan baik maka sudah pasti aktivitas belajar siswa pun juga membaik. Pada siklus II ini guru telah menerapkan strategi pembelajaran KWL dengan baik yang membuat siswa menjadi lebih aktif dari sebelumnya utamanya saat berdiskusi bersama teman kelompoknya, sehingga hasil yang diperoleh dapat lebih optimal. Temuan ini sejalan dengan hasil penelitian yang dilakukan oleh Zhang (2010) bahwa strategi Know-Want-Learned dapat mendorong pembelajaran menjadi aktif serta diinstruksikan dari guru kepada siswa dengan ketercapaian indikator kinerja sebesar 75\%, juga pendapat Rahmawati (2018, p. 245) yang menyatakan bahwa strategi pembelajaran KWL mampu meningkatkan pemahaman membaca siswa, melalui strategi ini siswa menjadi lebih aktif dan mandiri dalam melaksanakan tugas. Selain itu selama kegiatan pembelajaran suasana belajar tampak menyenangkan, memprovokasi, dan memotivasi siswa. Ini karena strategi KWL membutuhkan siswa untuk lebih mandiri dalam berpikir, seperti pada langkah pertama mengeksplorasi pengetahuan awal siswa tentang apa yang diketahui, langkah kedua menuntut siswa untuk mengembangkan rasa ingin tahu tentang apa yang ingin mereka ketahui dan langkah terakhir adalah membaca dan mendapatkan pengetahuan serta lebih banyak wawasan tentang topik tersebut. Ini membuat siswa lebih tertarik belajar membaca. Selain itu Rahim (2009, p. 41) juga menyatakan bahwa strategi KWL memberikan kepada siswa tujuan membaca dan memberikan suatu peran aktif siswa sebelum, saat dan sesudah membaca. Strategi ini membantu siswa memberikan informasi baru yang diterimanya. Strategi ini juga dapat memperkuat kemampuan siswa mengebangkan pertanyaan tentang berbagai topik dan dapat menilai hasil belajar mereka sendiri.

Pada penerapan strategi KWL dalam pembelajaran membaca pemahaman siklus II semua kelompok telah mengalami peningkatan karena telah berhasil mengisi tabel KWL dan mengerjakan lembar kerja dengan baik dibandingkan pada pembelajaran siklus I. Pada siklus II ini pembelajaran disertai dengan permainan dan pemberian hadiah dan hukuman sehingga siswa menjadi lebih aktif dan antusias dalam mengikuti pembelajaran. Terlebih saat melakukan permainan, siswa berlombalomba untuk menjadi kelompok terbaik dalam memahami bacaan yang dibuktikan dengan mengisi tabel KWL. Pemberian hadiah dan hukuman (Reward and punishment) merupakan bagian dari cara guru untuk memotivasi siswa dalam belajar. Penempatan reward dan punishment secara tepat dapat menjadi motivasi tersendiri pada diri siswa dalam menumbuhkembangkan minat siswa dalam melakukan aktivitas belajar. Pemberian hadiah dan hukuman (Reward and punishment) sangat penting dan juga sangat berpengaruh dalam memotivasi siswa, karena melalui reward dan punishment siswa akan menjadi lebih aktif untuk memahami materi, lebih percaya diri dan bertanggung jawab dengan tugas yang diberikan sehingga proses dan tujuan pembelajaran bisa tercapai secara optimal. Hal ini sejalan dengan hasil penelitian yang dilakukan oleh Sujiantari (2016) bahwa reward dan punishment secara simultan berpengaruh terhadap motivasi belajar siswa. Hal tersebut dikarenakan reward mencangkup beberapa aspek yaitu adanya penghargaan dari pendidik (guru), pujian, tepukan punggung, senyuman, kata-kata manis, dan hadiah. Sementara punishment diberikan kepada seseorang karena melakukan suatu kesalahan, perlawanan atau pelanggaran atau ketika siswa melanggar peraturan yang telah ditetapkan oleh guru, punishment dimaksudkan untuk perbaikan dan pembinaan tingkah laku siswa.

\section{Hasil Belajar Siswa (Kemampuan Membaca Pemahaman Siswa)}

Berdasarkan hasil observasi awal yang dilakukan oleh peneliti sebelum diterapkannya strategi Know-Want-Learned (KWL) ditemukan rendahnya hasil belajar siswa yang ditunjukkan 
dari dokumen guru yang berupa hasil ulangan tengah semester siswa pada tahun 2018/2019. Data awal menunjukkan bahwa dari 26 siswa hanya 10 orang siswa $(38,46 \%)$ yang mencapai KKM dengan rata-rata nilai 71,54. Ini menunjukkan bahwa lebih dari setengahnya atau 16 siswa $(61,54 \%)$ belum mencapai KKM. Setelah diterapkannya strategi pemebelajaran KWL, hasil belajar siswa mengalami peningkatan pada setiap siklusnya. Jika pada observasi awal persentase ketuntasan secara klasikal hanya mencapai 38,46\% maka pada siklus I mengalami peningkatan sebesar 16,54\%. Meskipun telah terjadi peningkatan pada siklus I, namun nilai tersebut masih rendah dan belum mencapai indikator keberhasilan yang telah ditetapkan yakni $80 \%$. Hasil belajar tersebut diperoleh berdasarkan proses pembelajaran yang dilaksanakan melalui sinergi antara keterampilan guru dan aktivitas siswa. Oleh karena keterampilan guru dan aktivitas siswa masih belum memenuhi kriteria keberhasilan pada siklus I, maka dapat dipastikan hasil belajar siswa pun belum baik. Karena hasil belajar merupakan perubahan perilaku yang diperoleh peserta didik setelah mengalami kegiatan belajar (Sudjana, 2011, p. 22). Setelah dilakukannya perbaikan pada siklus II, kembali terjadi peningkatan. Pada siklus I persentase ketuntasan secara klasikal mencapai $55 \%$ dan mengalami peningkatan sebesar 30\% pada siklus II menjadi $85 \%$ dengan rata-rata nilai yang diperoleh sebesar 84,8 . Untuk lebih jelasnya dapat dilihat pada Gambar 1 berikut :

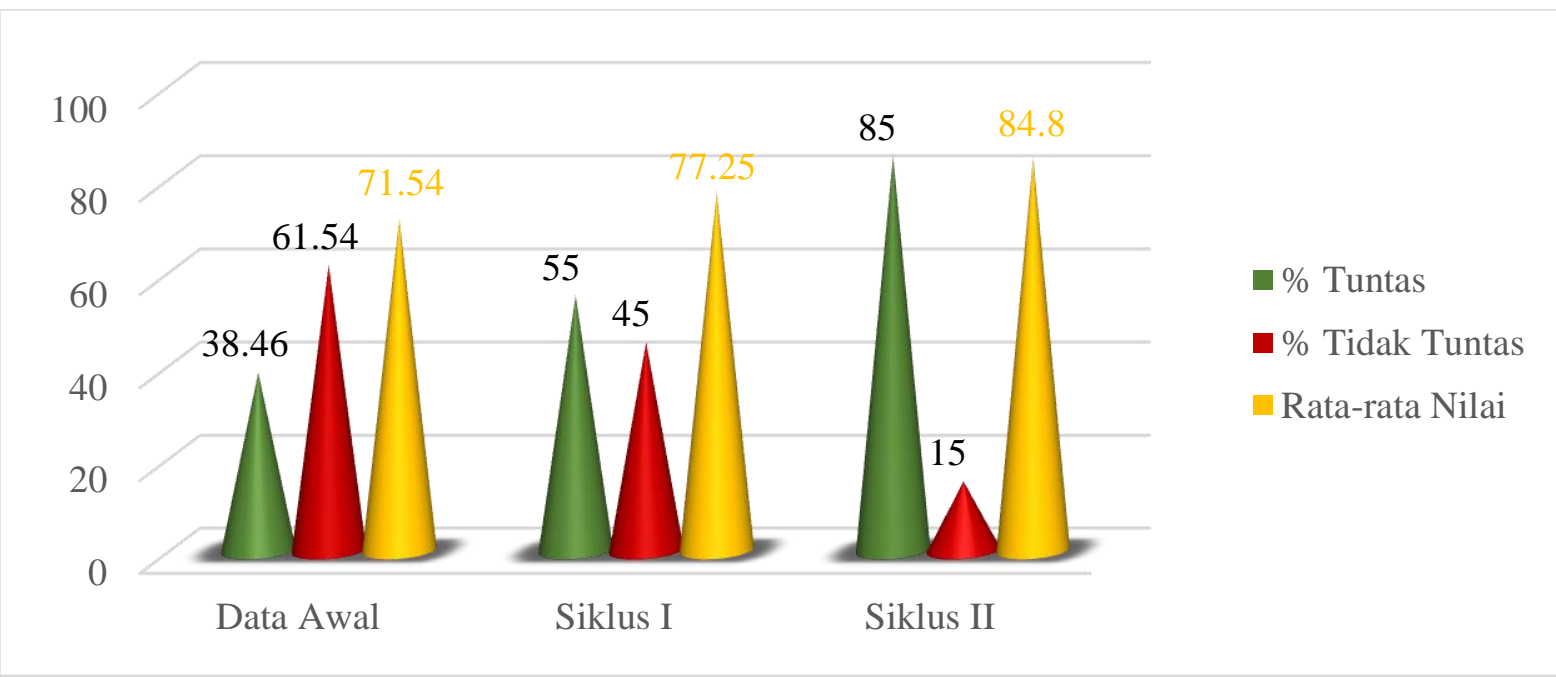

Gambar 1. Peningkatan Hasil Belajar Membaca Pemahaman Siswa

Berdasarkan data hasil evaluasi di atas, menunjukkan bahwa kemampuan membaca pemahaman siswa kelas IV-B SD Negeri 24 Kendari dapat ditingkatkan melalui penggunaan strategi pembelajaran Know-Want-Learned (KWL). Hasil penelitian ini didukung oleh beberapa penelitian sebelumnya yaitu penelitian yang dilakukan oleh Riswanto (2014) yang mengungkapkan bahwa strategi KWL efektif dalam meningkatkan pemahaman membaca siswa. Efektivitasnya ditunjukkan oleh hasil regresi bahwa kontribusi strategi KWL terhadap kemampuan membaca siswa adalah 70,5\%. Juga penelitian yang dilakukan oleh Thi Thanh Dieu (2015) yang menunjukkan bahwa penerapan strategi KWL memberikan pengaruh terhadap kemampuan pemahaman siswa karena strategi ini mampu mengontrol kelas dalam membaca, membuat suasana yang menarik dan menyenangkan sehingga pemahaman bacaan siswa dapat meningkat. Hal ini juga sejalan dengan pendapat Herlinyanto $(2015$, p. 4) yang mengatakan bahwa penerapan strategi KWL sangat baik digunakan dalam membaca pemahaman, karena karakteristik KWL sesuai untuk meningkatkan kemampuan siswa dalam memahami teks bacaan. Karakteristik yang dimaksud yaitu: (1) siswa mengingat kembali pengetahuan yang dimilikinya berhubungan dengan topik, (2) siswa memprediksi isi bacaan berdasarkan pengetahuan yang dimilikinya dengan mencermati topik yang disajikan guru sebelum membaca, (3) siswa membuat pertanyaan-pertanyaan mengenai apa yang ingin dipelajarinya, (4) siswa membaca dalam hati dan menemukan informasi yang ingin diketahuinya dari bacaan atas bimbingan guru, dan (5) siswa mencatat semua informasi dan kesimpulan isi bacaan. Hal serupa juga diungkapkan oleh Rahim (2009, p. 41) bahwa dengan 
penerapan strategi KWL dalam pembelajaran siswa akan lebih mudah dalam memahami isi bacaan, sehingga siswa mampu menjawab pertanyaan yang berkaitan dengan isi bacaa, mampu menemukan ide pokok setiap paragraf, mampu menarik simpulan atas paragraf yang telah dibaca, serta mampu menarik simpulan yang sesuai dengan isi paragraf.

\section{Simpulan}

Berdasarkan hasil analisis data dan pembahasan hasil penelitian maka dapat disimpulkan bahwa penerapan strategi pembelajaran KWL (Know-Want-Learned) dapat meningkatkan kemampuan membaca pemahaman siswa Kelas IV-B SDN 24 Kendari, utamanya dalam hal menjawab pertanyaan berdasarkan teks bacaan, menemukan informasi baru atau penting dari teks, menentukan ide pokok dan menyimpulkan isi teks bacaan dalam satu kalimat. Peningkatan tersebut ditunjukkan dengan nilai persentase ketuntasan belajar siswa yang mengalami peningkatan pada setiap siklusnya, dimana pada data awal sebelum diterapkannya strategi KWL persentase ketuntasan secara klasikal mencapai 38,46\% dengan rata-rata nilai 71,54. Setelah diterapkannya strategi pembelajaran KWL persentase ketuntasan secara klasikal pada siklus I mencapai 55\% dengan rata-rata nilai 77,25 dan pada siklus II persentase ketuntasan klasikal mencapai 85\% dengan rata-rata nilai 84,8 .

\section{Daftar Pustaka}

Herlinyanto. (2015). Membaca Pemahaman Dengan Strategi KWL (Pemahaman dan Minat Baca). Yogyakarta: CV. Budi Utami.

Maulana, P. (2018). Penerapan Metode KWL (Know-Want To Know-Learned) Untuk Meningkatkan Motivasi Belajar Dan Kemampuan Membaca Pemahaman. 2(2), 48-54. https://jurnal.stkip1 1april.ac.id/index.php/JESA/article/viewFile/49/50

Melinda, I., \& Susanto, R. (2018). Pengaruh Reward dan Punishment Terhadap Motivasi Belajar Siswa. International Journal of Elementary Education, 2(2), 81-86. Retrieved from https://ejournal.undiksha.ac.id/index.php/IJEE

Nurcahyanti, B. (2018). Peningkatan Keterampilan Membaca Pemahaman Melalui Metode KWL Pada Siswa Kelas V. Jurnal Pendidikan Guru Sekolah Dasar, 3(1), 194-202. http://journal.student.uny.ac.id/ojs/index.php/pgsd/article/view/10650

Rahim, F. (2009). Pengajaran Membaca Di Sekolah Dasar. Jakarta: Bumi Aksara.

Rahmawati, E. Y. (2018). Analysis of Students' English Reading Comprehension through KWL (Know-Want-Learn) Learning Strategies. International Journal of Language Teaching and Education, 2(3), 238-247. https://doi.org/10.22437/ijolte.v2i3.5641

Riswanto, Risnawati, \& Lismayanti, D. (2014). The Effect of Using KWL (Know, Want, Learned) Strategy on EFL Students' Reading Comprehension Achievement. International Journal of Humanities and Social Science, 4(7), 225-233. https://doi.org/doi=10.1.1.1062.3444

Rustan, E. (2017). Learning Creative Writing Model Based on Neurolinguistic Programming. International Journal of Language Education and Culture Review, 3(2), 13-29. https://doi.org/10.21009/IJLECR.032.02

Sanjaya, W. (2011). Penelitian Tindakan Kelas. Jakarta: Kencana Prenada Media Group.

Sudjana, Nana. (2010). Dasar-Dasar Proses Belajar Mengajar. Bandung: Sinar Baru Algensindo. 
Jurnal Ilmiah Pembelajaran Sekolah Dasar

Volume 2 Nomor 2 - Agustus 2020, e-ISSN 2656-0402

Available online at:http://ojs.uho.ac.id/index.php/jipsd

Sujiantari, N. K. (2016). Pengaruh Reward dan Punishment terhadap Motivasi Belajar Siswa dalam Pembelajaran IPS (Studi pada SMP Negeri 1 Singaraja kelas VIII Tahun Ajaran 2015/2016). Jurnal Jurusan Pendidikan Ekonomi (JJPE), 7(2), 1-10. https://doi.org/http://dx.doi.org/10.23887/jjpe.v7i2.7573

Thi Thanh Dieu, T. (2015). Trying K-W-L Strategy on Teaching Reading Comprehension to Passive Students in Vietnam. International Journal of Language and Linguistics, 3(6), 481. https://doi.org/10.11648/j.ij11.20150306.33

Zhang, F. (2010). The Integration of the Know-Want-Learn (KWL) Strategy into English Language Teaching for Non-English Majors. Chinese Journal of Applied Linguistics, 33(4), 77-86. http://www.celea.org.cn/teic/92/10120605.pdf 